\title{
Biokaasuun perustuvan energiantuotannon mahdollisuudet suomalaisessa maataloudessa
}

\author{
Petri Kapuinen \\ Maa- ja elintarviketalouden tutkimuskeskus, maatalousteknologian tutkimus, Vakolantie 55, 03400 \\ VIHTI, petri.kapuinen@mtt.fi
}

Mädätyksessä lannan orgaaninen aines hajotetaan hallituissa olosuhteissa metaaniksi ja hiilidioksidiksi. Metaani käytetään sähkön ja lämmön tuotantoon tai moottoriajoneuvoissa. Pelkän lannan mädättäminen on harvoin kannattavaa, vaan mukaan tarvitaan erilaisia helposti hajoavia lisämateriaaleja. Lisämateriaaleja voidaan tuottaa pelloilla tai sitä voidaan hankkia tilan ulkopuolelta. Nykyisessä tukijärjestelmässä peltobiomassaa ei käytännössä voi tuottaa CAP-kesantopellolla, mutta sitä voi tuottaa esimerkiksi rehualalla. Tuotanto on kohtuullisen kannattavaakin suhteessa kesannolla tuottamiseen, jos tilalla on kansalliseen nurmitukeen oikeuttava määrä märehtijöitä ja hevosia. Karjatiloilla on yleisesti liikaa rehualaa eläinten rehuntuottamiseen nykyisten laajaperäisyystukien takia. Rasvat ovat parhaita lisämateriaaleja, koska niiden kaasutuotanto on suuri eikä niiden sekoittamiseen lietteen sekaan tarvita niiden juoksevuuden takia kustannuksia lisääviä sekoittamoja.

Peltobiomassojen mädätys sähköntuotantoa silmällä pitäen on taloudellisesti mielekästä, kun sähkölle saatava korvaus on merkittävästi suurempi kuin lämpöenergialle. Pelkkää lämmöntuotantoa varten kuiva biomassa kannattaa polttaa. Ratkaisevan muutoksen biokaasulaitosten kannattavuuteen saattaa tuoda erilliskerätystä biojätteestä perittävät ns. porttimaksut, kun niitä ei enää saa viedä kaatopaikoille. Näistä saattavat tuotot saattavat ylittää tuotetun energian arvon. Lietteen sekaan voidaan liettää myös kuivalantaa, joten mädätys ei rajoitu pelkästään lietelantaan, jonka osuus suomessa tuotetusta lannasta on vain noin $40 \%$. Varsinainen kuivamädätystekniikka on vasta kehitysvaiheessa.

Maatalouden teoreettinen biokaasupotentiaali (542 milj. $\mathrm{m}^{3} ; \mathrm{n} .3,5 \mathrm{TWh}$ ) edustaa noin $75 \%$ Suomen koko biokaasupotentiaalista, mutta se on varsin vähäisessä määrin hyödynnetty. Suomessa on tällä hetkellä vain viisi toimivaa biokaasulaitosta maatiloilla, mutta uusien laitoksia on odotettavissa, koska MMM:n suhtautuminen niiden tukemiseen on muuttumassa. Suhtautumisen muutoksen takana on paineet vähentää kasvihuonekaasupäästöjä. Biokaasun käyttö vähentää niitä toisaalta korvaamalla fossiilisia polttoaineita ja toisaalta vähentämällä levitetystä lannasta syntyviä päästöjä. Näistä ensin mainittu vaikutus on merkittävämpi, mutta se lasketaan energiasektorin ei maatalouden päästövähennykseksi. Lannan osuus kaikista metaanipäästöistä on vain $7 \%$. Maatilojen biokaasutuotantoa voidaan perustella myös lannan ravinteiden hyväksikäytön paranemisella, paremmalla hygienialla, hajuhaittojen vähenemisellä, maaseudun kehitystä tukevilla positiivisilla taloudellisilla ja työllisyysvaikutuksilla. Lisäksi se hajautettuna energiantuotantomuotona lisäisi maatalouden ja maaseudun energiaomavaraisuutta sekä huoltokykyä kriisitilanteissa.

Laitosten pieneen määrään tärkeimpänä syynä on niiden huono kannattavuus suomalaisten tilojen ollessa pieniä ja sähkön hinta. Tilannetta Suomessa huonontaa se, että suurin osa noin 80 \% Suomessa tuotetusta lannasta on nautakarjan lantaa, jonka kaasuntuotanto on merkittävästi pienempi kuin sianlannan. Nautakarjataloutta harjoitetaan tyypillisesti suhteellisen pienissä yksiköissä. Kannattava toiminta edellyttäisi keskitettyjä laitoksia. Lisäksi toiminta jää nykyisen lainsäädännön vallitessa väliinputoajaksi erilaisista energiantuotannon tukimuodoista. Laitoksia ovat rakentaneet alan pioneerit hartiapankkirahoituksella. Biokaasuun perustuva energiantuotanto on huomattavasti yleisempää maissa, joissa biokaasutuotantoa tuetaan biokaasulla tuotetun sähkön hinnan kautta. Saksassa biokaasusähköstä maksetaan lakisääteisesti noin10 snt/kWh. Suomessa hinta on yleisesti noin $2 \mathrm{snt} / \mathrm{kWh}$ ja parhaatkin maksetut hinnat ovat noin 5,5 snt $/ \mathrm{kWh}$. Tämä on johtanut siihen, että Saksassa toimii maatiloilla noin 2000 biokaasulaitosta, mutta Suomessa määrä on jäänyt nykyiselleen. Parhaan hinnan tila saa tuottamalleen sähkölle käyttämällä sen omalla tilalla, koska ostajan maksamat sähkön hintaan sisältyvä sähkönsiirtomaksu ja sähkövero jäävät tavallaan tilan hyödyksi. Ongelmana on kuitenkin biokaasutuotannon ja tilan sähkönkulutuksen erilainen ajoittuminen. Biokaasua syntyy eniten kesällä ja sähköä kulutetaan eniten talvella. Jos kaikki lanta mädätettäisiin, tuotettu sähkö riittäisi kattamaan maatalouden kulutuksen tai sähköverkon häviön, joten suurvoimaloita biokaasutuotannolla ei voida korvata. Lisäksi realistinen arvio mädätettävän lannan määrästä on noin $5 \%$, jos biokaasusähköntuotantoa tuettaisiin samalla tasolla kuin Saksassa. Se voisi kuitenkin lisätä merkittävästi maatalouden energiaomavaraisuutta myös sähkön osalta. Nykyisellä kaupallisella teknologialla sähkön tuottaminen uusiutuvilla energialähteillä onnistuu maatilamittakaavassa vain polttomoottoreilla ja generaattorilla käyttäen polttoaineena biokaasua tai öljykasvien öljyä. 